\title{
The GSSP of the Second (Upper) Stage of the Lower Ordovician Series: Diabasbrottet at Hunneberg, Province of Västergötland, Southwestern Sweden
}

\author{
1 Department of Geological Sciences, The Ohio State University, 155 S. Oval Mall, Columbus, OH 43210, USA.(stig@geology.ohio-state.edu) \\ 2 Department of Geology, Lund University, Sölvegatan 12, SE-22362 Lund, Sweden. \\ 3 Department of Geology, State University of New York at Buffalo, Box 603050, Buffalo, NY 14260 - 3050, USA.
}

\begin{abstract}
Diabasbrottet, selected by the International Subcommisson on Ordovician Stratigraphy and in 2002 ratified by the International Commission on Stratigraphy as the GSSP of the Second (Upper) Stage of the Lower Ordovician, is located on the Hunneberg Mountain in southwestern Sweden. The stratigraphic succession represents an outer shelf environment near the Baltic Shield margin. The shale-dominated, biostratigraphically complete, richly fossiliferous boundary interval is completely exposed in a disused quarry. The GSSP is in the lower TØyen Shale 2.1 m above the top of the Cambrian and is marked by the first appearance of the graptolite Tetragraptus approximatus Nicholson. The boundary interval contains a diverse graptolite fauna and biostratigraphically diagnostic conodonts and trilobites that make it possible to define the boundary in terms of zone schemes based on these groups. In this respect, the Diabasbrottet and nearby sections are unique in the world among described localities having this boundary interval. Based on the appearance of T. approximatus, the base of the Second Stage can be identified in many graptolitiferous successions round the world but this level is currently more difficult to recognize precisely in some carbonate sequences outside Baltoscandia. We propose the Second Stage be called the Floan Stage. It is named for the Village of Flo, which is situated about $5 \mathrm{~km}$ southeast of the GSSP.
\end{abstract}

\section{Introduction}

For the past 15 years, one of the principal activities of the International Subcommision on Ordovician Stratigraphy (ISOS) of the International Commission on Stratigraphy (ICS) has been to establish a scheme of global series and stages for the Ordovician System. Because previous chronostratigraphic units of this type have been of provincial character and largely based on fossils with limited geographic distribution, these series and stages have been difficult, or impossible, to correlate globally. Series terms such as 'Lower' and
'Upper' Ordovician have had a rather different scope in different parts of the world as was recognized by Jaanusson (1960) almost half a century ago. This has led to confusion among non-stratigraphers concerned about historical paleogeography and palebiogeography, fossil evolution and fossil diversity trends through time, paleoceanographic evolution and other such matters where precise time relations are of critical importance.

In an effort to establish a globally applicable Ordovician chronostratigraphy, various working groups of the ISOS have investigated biostratigraphic horizons that appeared to have potential for reliable international correlations. This work resulted in the recognition of six levels (Figure 1) that seemed to have particular promise as stage and series boundaries and these were approved by ISOS for detailed assessment (Webby, 1996). Recently, the stage levels in the Upper Ordovician have been slightly modified. Previous work, summarized by Cocks and Rickards (1988), led to the decision to have the base of the Parakidograptus acuminatus Zone at Dob's Linn, South Scotland as GSSP for the base of the Silurian, thereby defining the top of both the Upper Ordovician Series and the uppermost Ordovician stage. This GSSP was ratified by the ICS in 1985. Very comprehensive work during some 25 years finally resulted in the selection of the first appearance level of the conodont Iapetognathus

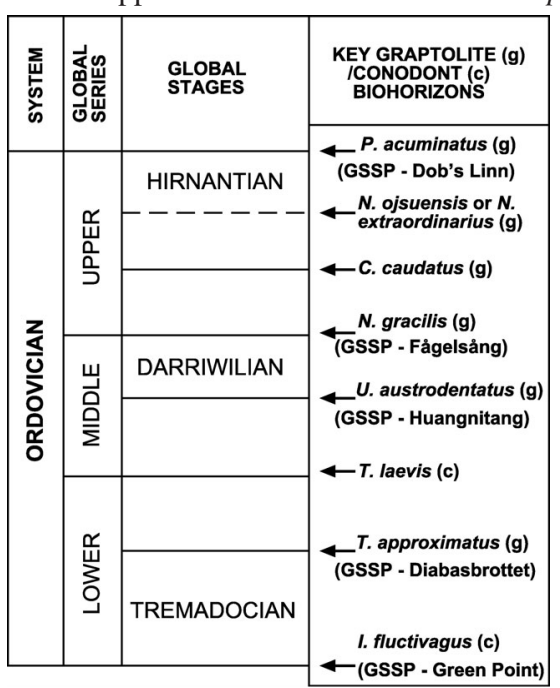

Figure 1 Diagram showing biohorizons approved for defining the base of global series and stages in the Ordovician. (g) and (c) refer to graptolites and conodonts, respectively. Note that in view of unexpected taxonomic and other problems with T. laevis, another species will probably be used to define the base of the Middle Ordovician Series. 
fluctivagus at Green Point, western Newfoundland as the GSSP for the base of the Ordovician (Cooper et al., 2001). This GSSP selection, which was ratified by the ICS in 2000 , defined not only the base of the system but also the base of the Lower Ordovician Series and the first (lower) stage of the Lower Ordovician, for which the name Tremadocian Stage was approved by an ISOS vote in 2000 (Cooper et al., 2001).

Progress in selecting GSSPs for series and stages within the Ordovician was initially somewhat slow but has accelerated in recent years. The base of the Undulograptus austrodentatus Zone in the Huangnitang section in S.E. China was selected as GSSP for the base of the upper Middle Ordovician Darriwilian Stage (Chen and Bergström, 1995; Mitchell et al., 1997) and ratified by the ICS in 1997. Recently, the level of first appearance of the graptolite Nemagraptus gracilis in the Fågelsång section, $\mathrm{S}$. Sweden (Bergström et al., 2000) was selected as the GSSP of the base of the Upper Ordovician Series and the base of the lower stage of this series. This selection was ratified by the ICS in 2002.

The ISOS decided in 1996 that the base of the Second (Upper) Stage of the Lower Ordovician would be the level of first appearance of the graptolite Tetragraptus approximatus (Webby, 1996). A world-wide search for a suitable GSSP included fieldwork, literature reviews, and extensive ISOS discussions. At the time of the 8th International Symposium on the Ordovician System in Prague 1999, two sections had emerged as principal GSSP candidates, namely "The Ledge" section on the Cow Head Peninsula, western Newfoundland (Williams et al., 1994) and the Diabasbrottet section at Hunneberg, S.W. Sweden (Maletz et al., 1996). During special sessions at the Prague Symposium, the pros and cons of these sections were discussed in considerable detail. In a subsequent voting in 2000 , the Diabasbrottet section was favored over the "The Ledge" section by the voting members of the ISOS by a vote of 16 for Diabasbrottet, 4 for "The Ledge", and 1 abstain. In an ISOS postal vote in 2000 following further discussion, the Diabasbrottet was favored as a GSSP for the base of the Second (Upper) Stage, to be officially named later, of the Lower Ordovician by a vote 20 for and 1 against. This decision was ratified by the ICS in 2002. Formal dedication ceremonies, which involved the unveiling of an information plaque and hammering into the shale of a 'golden spike', took place in May, 2003 with participation of geologists from 12 nations. This was the culmination of almost a decade of work and discussions.

The purpose of the present paper is to summarize important data on the Diabasbrottet GSSP. We also propose the Floan Stage as a suitable designation for the previously unnamed Second Stage. For additional information, see Löfgren (1993), Maletz et al. (1996), and Löfgren and Bergström (2002)

\section{Geographic and geologic setting}

The Diabasbrottet GSSP is located near the northern end of a large quarry along the north-eastern slope of Hunneberg (UPM coordinates UE $53957160 ; 58^{\circ} 21^{\prime} 32.2^{\prime \prime} \mathrm{N}$ latitude, $12^{\circ} 30^{\prime} 08.6^{\prime \prime} \mathrm{E}$ latitude), a prominent mountain in the northwesternmost part of the Province of Västergötland in southwestern Sweden (Figure 2). It is about $80 \mathrm{~km} \mathrm{N.N.E.} \mathrm{of} \mathrm{the} \mathrm{City} \mathrm{of} \mathrm{Göteborg} \mathrm{(Gothenburg)} \mathrm{that} \mathrm{has}$ an international airport, and about $12 \mathrm{~km}$ E.S.E. of the town of Vänersborg that is served by national airlines. The GSSP exposure is in the shale wall just adjacent to the southernmost underground mine in the Upper Cambrian Alum Shale (Maletz et al., 1996, Figure 2) a few tens of $m$ off the northern entrance road into the quarry from Highway 2050. From this major highway the section can easily be reached by driving on the quarry entrance road to the northern end of the quarry and then walking a few tens of $m$ northwestward on a small path across wooded shale piles to the old N.W.-S.E. oriented quarry wall (Figure 2C). The section, which is Section 2 of Löfgren (1993, Figure 1c), is now marked by an information sign in Swedish and English, and the level of the key stratigraphic horizon is indi-

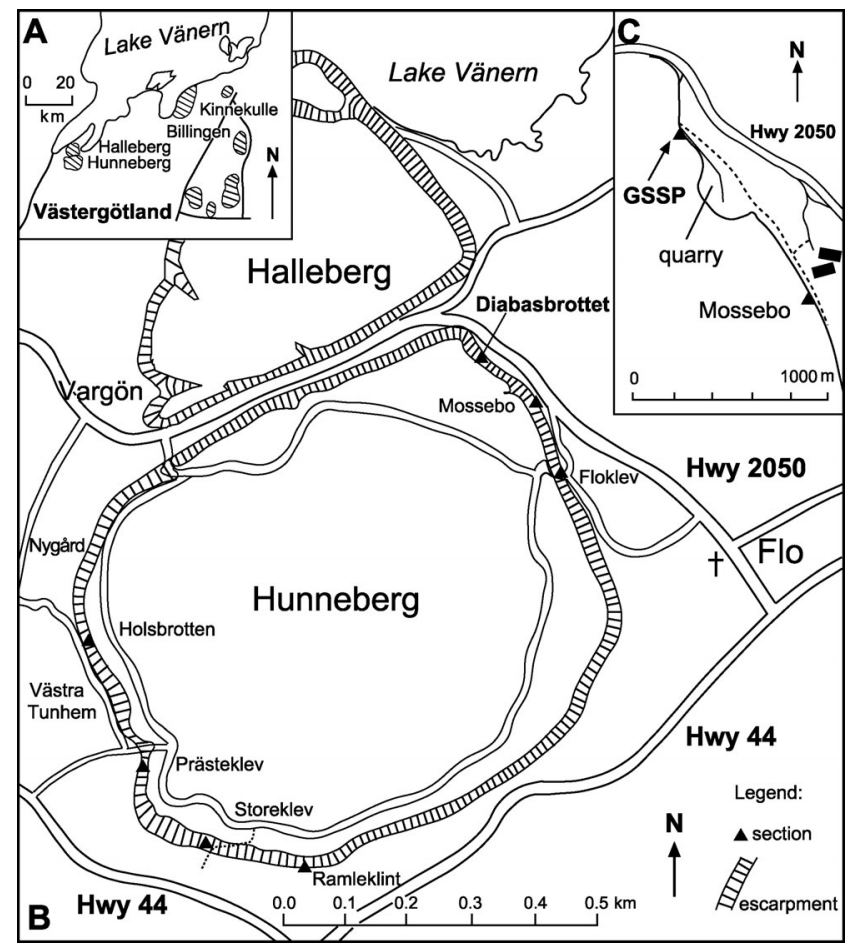

Figure 2 A-sketch-map showing location of Hunneberg in the Province of Västergötland. B-map of the Hunneberg area. Note location of Diabasbrottet, Mossebo, and other localities along the slope of the mountain. C-detailed map of the DiabasbrottetMossebo area. The Lower Ordovican outcrops are located along a N.-S. quarry wall that extends for more than $1 \mathrm{~km}$ from Diabasbrottet southward to S. of Mossebo.

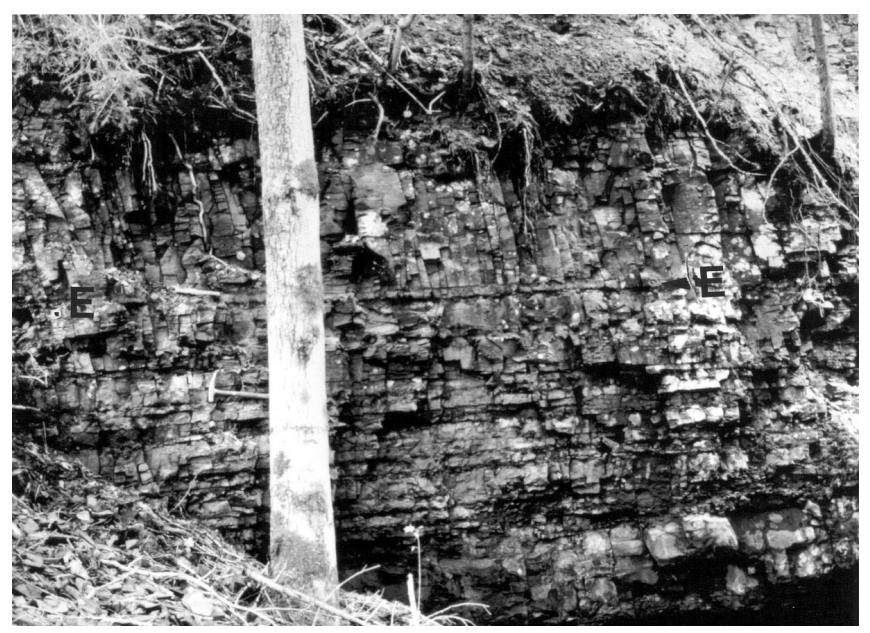

Figure 3 Photograph of the Diabasbrottet GSSP. The base of the Second Stage is marked by the ruler on the top of the $E$ bed (marked E).

cated by a 'golden spike' that has been hammered into the shale. For a photo of the section, see Figure 3.

\section{The Diabasbrottet section}

The GSSP outcrop provides a complete and easily accessible exposure of not only the stage boundary interval but also of Late Cambrian and earliest Ordovician (Tremadocian) units. The succession is highly condensed, the exposed Ordovician sequence being only about $12 \mathrm{~m}$ thick, but it is remarkably complete stratigraphically. For a diagrammatic illustration of the studied part of the succession, see Figure 4. 


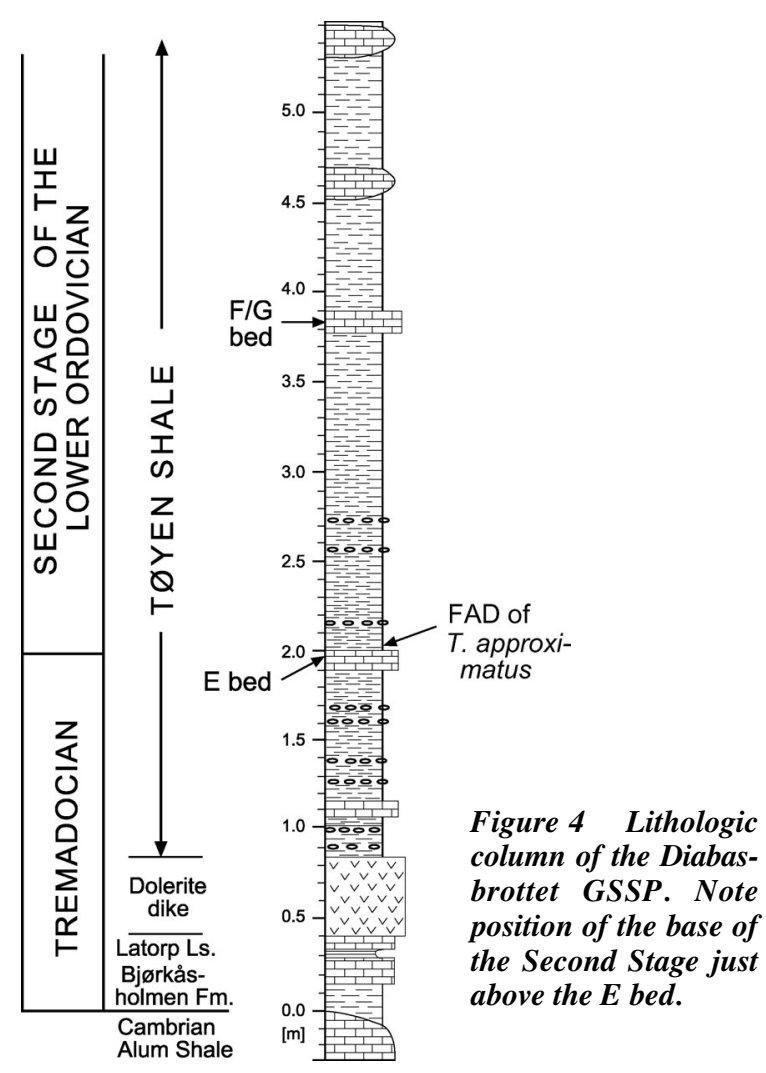

\section{Lithology and lithostratigraphy}

The oldest rocks exposed at Diabasbrottet belong to the Upper Cambrian Alum Shale that has been quarried extensively not only at this quarry but in numerous other quarries along the basal slopes of Hunneberg. It may reach a total thickness of about $15 \mathrm{~m}$ but only the upper few $\mathrm{m}$ are currently exposed in the Diabasbrottet area, mostly in shallow mine shafts. As is the case in other parts of southern and central Scandinavia, this unit is a lithologically rather monotonous succession of black fissile shales with nodules and beds of dark-grey to brown, fine to coarse-grained, rather pure, frequently quite fossiliferous limestone. At some Hunneberg sections, but not at Diabasbrottet, the Cambrian shale is overlain by an up to $1 \mathrm{~m}$ thick black shale, which is generally included in the Alum Shale but which contains earliest Ordovician (early Tremadocian) fossils such as Rhabdinopora flabelliformis.

On the top of this shale follow, probably disconformably, two thin, lithologically somewhat variable, units of mostly dark limestone, the Bjørkåsholmen Formation (formerly the Ceratopyge Limestone) and the Latorp Limestone (formerly the armata Limestone), both of late Tremadocian age. The combined thickness of these units, which are quite fossiliferous and contain distinctive trilobite and conodont faunas, is less than $1 \mathrm{~m}$. This part of the Diabasbrottet succession is intruded by an approximately $0.5 \mathrm{~m}$ thick dolerite dike (Maletz et al., 1996, Figure 4). The Latorp Limestone is overlain by a more than $10 \mathrm{~m}$ thick unit, referred to as the Tøyen Shale, which includes grey to dark shale and mudstone with thin interbeds of fine-grained dark limestone, especially in the lowermost part. Two of these interbeds, referred to as the $\mathrm{E}$ and $\mathrm{F} / \mathrm{G}$ beds by Maletz et al. (1996), can be traced from quarry to quarry over long distances and serve as useful lithologic marker beds. The Tøyen Shale is overlain by a $60-70 \mathrm{~m}$ thick cover of dolerite that was intruded into the sedimentary succession as sills and dikes in early Permian time. This hard protective cover has prevented the relatively soft Cambro-Ordovician strata from being removed by erosion as has happened in areas outside the dolerite cover where Precambrian crystalline rocks form the peneplained bedrock surface.
In having a very substantial amount of fine-clastic material, the Lower Ordovician Hunneberg succession is similar to coeval successions in the Oslo region in Norway and in Scania, southernmost Sweden but very different from the far more calcareous sequences in central Sweden and the more eastern parts of the Baltoscandian Shield. This regional facies difference, which is also reflected in the faunas, mirrors significant differences in depositional environments, and served as a basis for Jaanusson's (1995) recognition of the socalled Scanian-Oslo confacies belt and the Central Baloscandian confacial belt (Figure 5). The former confacies belt, which includes the Hunneberg area, occupied a more marginal position on the Baltoscandian craton and is characterized by dominating shales deposited in moderately deep to deep environments in an outer shelf or foreland basin environment. Corresponding strata in the Central Baltoscandian belt are mostly cold-water, rather pure, limestones with rich shelly faunas that were laid down in moderately deep water with little influx of clastic material.

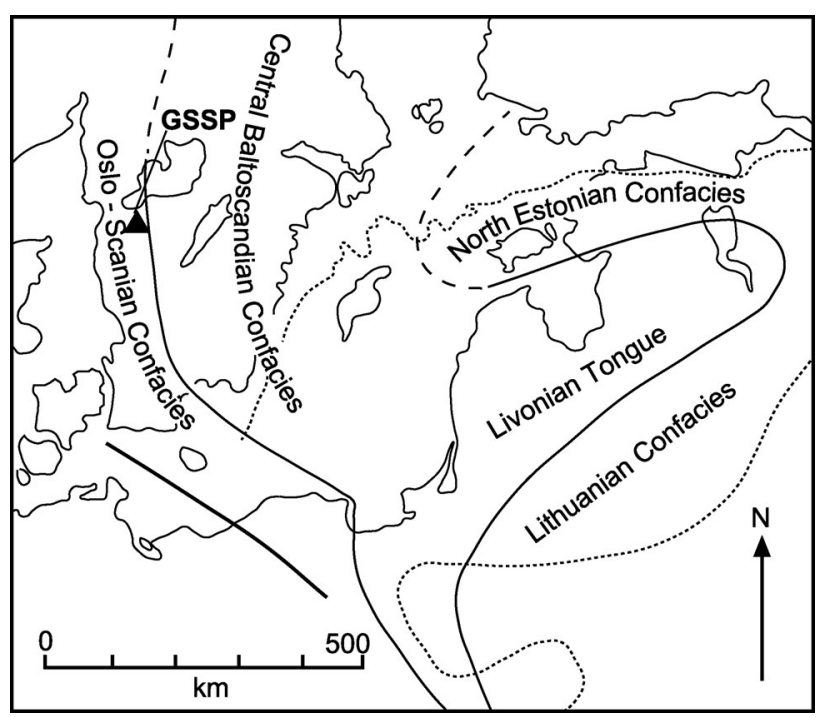

Figure 5 Map illustrating the location of the Diabasbrottet section within the Oslo-Scanian Confacies Belt. Confacies belt distribution after Jaanusson (1995).

\section{Sequence stratigraphy}

The Ordovician of the Hunneberg area has not yet been studied in terms of sequence stratigraphy, but it is of interest to compare this succession with the interpretation of Dronov and Holmer (1999) of the sequence stratigraphy of coeval successions in the Billingen and Kinnekulle areas, which are located only about $70 \mathrm{~km} \mathrm{N.E.} \mathrm{of,} \mathrm{and}$ $55 \mathrm{~km}$ E. of, Hunneberg, respectively (Figure 2). They recognized the early Tremadocian Shale with Rhabdinopora flabelliformis as a transgressive systems tract of the Pakerort Sequence (Figure 6). The Bjørkåsholmen Formation was interpreted as a lowstand system tract in the overlying Latorp Sequence, which was followed by the transgressive Latorp-Tøyen succession with the latter unit representing the highstand of that sequence. A similar interpretation was recently presented by Nielsen (2003). However, we believe that the sequence stratigraphic history is more complex. That is, Dronov and Holmer (1999) and Nielsen (2003) did not discuss the important fact that the Prioniodus elegans Zone is missing in most of the Central Baltoscandian Confacies Belt in south-central Sweden (Bergström, 1988). This zone represents a significant stratigraphic interval in many sections outside Baltoscandia as shown by the fact that it is about $60 \mathrm{~m}$ thick in the Precordillera of Argentina (Albanesi, 1998) and about $12 \mathrm{~m}$ thick in western Newfoundland (Stouge and Bagnoli, 1988). The stratigraphic gap of this missing zone is likely to represent a significant lowstand that has left no clear record in deeper-water successions such as that at Hunneberg, where the $P$. elegans Zone has a thickness of several m (Bergström, 1988). The Oepikodus evae-bearing Tøyen Shale in the Kinnekulle-Billingen area was laid down during the following highstand, which reflects a 


\begin{tabular}{|c|c|c|c|c|c|c|c|c|c|}
\hline 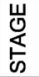 & $\begin{array}{l}\text { GRAPTOLITE } \\
\text { ZONES }\end{array}$ & $\begin{array}{l}\text { ATLANTIC } \\
\text { CONODONT } \\
\text { ZONES }\end{array}$ & $\begin{array}{c}\text { BALTOSCAN- } \\
\text { DIAN } \\
\text { STAGES }\end{array}$ & \multicolumn{2}{|c|}{$\begin{array}{l}\text { DEPOSITIONAL } \\
\text { SEQUENCES }\end{array}$} & KINNEKULLE & BILLINGEN & $\begin{array}{l}\text { DIABAS- } \\
\text { BROTTET } \\
\text { AREA }\end{array}$ & $\begin{array}{l}\text { INFERRED } \\
\text { SEA LEVEL } \\
\text { CURVE }\end{array}$ \\
\hline 岁 & \multirow{3}{*}{ D. hirundo } & B. norrlandicus & \multirow{3}{*}{ VOLKHOVIAN } & \multirow{3}{*}{3} & \multirow[b]{2}{*}{ VOLKHOV } & & & \multirow{5}{*}{ 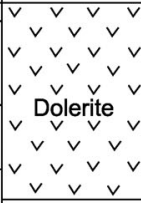 } & \multirow[t]{3}{*}{$\mathrm{H}$} \\
\hline$\frac{5}{0}$ & & $P$. originalis & & & & Lanna Ls. & Lan & & \\
\hline \multirow{5}{*}{ 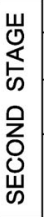 } & & B. nav./B. triang. & & & & & & & \\
\hline & Ph. densus & Oe. evae & $\begin{array}{l}\text { BILLINGEN- } \\
\text { IAN }\end{array}$ & \multirow{7}{*}{2} & HS & & Sh & & \\
\hline & D. balticus $\mid \dot{x}$ & $P$ elegans & \multirow{4}{*}{$\underset{\text { IAN }}{\text { HUNNEBERG }}$} & & LS & & & & \\
\hline & T. phyllo- $\quad \frac{2}{\sigma} \mid$ & & & & & & & \multirow{3}{*}{$\begin{array}{l}\text { Tøyen } \\
\text { Shale }\end{array}$} & \\
\hline & graptoides $\mid \leftarrow$ & \multirow[b]{2}{*}{ P. proteus } & & & \multirow[b]{5}{*}{ |PAKERORI } & \multirow{2}{*}{\multicolumn{2}{|c|}{ Latorp Limestone }} & & \\
\hline \multirow{4}{*}{ 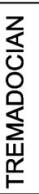 } & $\begin{array}{l}\text { H. copiosus } \\
\text { A. murrayi eq. }\end{array}$ & & & & & & & & \\
\hline & K. supremus & \multirow{2}{*}{ P. deltifer } & \multirow[b]{2}{*}{ VARANGUAN } & & & & & jøørkåsholmen & \\
\hline & A. hunnebergensis & & & & & & & & \\
\hline & R. flabelliformis & Cordylodus & PAKERORTIAN & 1 & & & & Rhabdinopora & \\
\hline
\end{tabular}

Figure 6 Baltoscandian depositional sequences recognized by Dronov and Holmer (1999) correlated with chronostratigraphic units and formations in the Diabasbrottet, Billingen, and Kinnekulle areas. The inferred sea level curve applies to the Diabasbrottet area that was characterized by deep-water deposition during much of the Early Ordovician. In most of the Central Confacies Belt (for instance, Kinnekulle and Billingen), the Prioniodus elegans Zone is missing. We interpret this as a lowstand (LS). Hence the Latorp depositional sequence of Dronov and Holmer (1999) includes two highstands (HS) separated by a lowstand.

prominent eustatic transgression referred to as the Evae transgressive event by Bergström (1988, Figure 9). Hence the Latorp depositional sequence of Dronov and Holmer (1999) includes two highstands separated by a lowstand, and their sequence stratigraphy needs some revision.

In view of its wide geographic distribution in the Hunneberg area and its close association with the Second Stage boundary, the thin limestone layer in the Tøyen Shale known as the E bed is of special interest in the Latorp Cycle. It appears to represent an event bed, possibly formed during a brief shallowing episode, but the fact that it locally consists of a layer of limestone nodules in shale rather than a solid limestone bed (Maletz et al., 1995, fig. 3) is consistent with the biostratigraphic evidence that it is not associated with a stratigraphic gap. Similar thin limestone beds are known from different levels in the Tøyen Shale at other localities in the Hunneberg area and elsewhere in the Province of Västergötland (Tjernvik, 1956) but these beds do not appear to have more than a very local distribution.

\section{Biostratigraphy}

The Hunneberg Ordovician successions have been studied for more than a century, but the key investigations are relatively few. They include Törnquist's $(1901,1904)$ classic graptolite work, Tjernvik's (1956) trilobite work, Löfgren's detailed conodont work (1993), and the graptolite investigations by Lindholm (1991), Erdt-

DIABASBROTTET
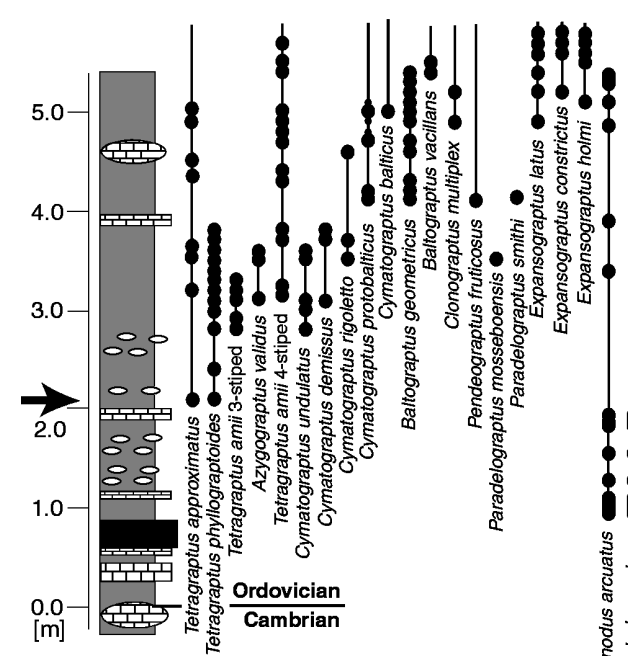

mann et al. (1987), and Maletz (1987). A detailed summary of the biostratigraphy based on these index fossils was presented by Maletz et al. (1996), and reference is made to that publication for additional modern information.

The Tøyen Shale and subjacent Ordovician strata at Diabasbrottet and nearby sections have yielded the most diverse fauna of graptolites known from that interval anywhere in the world (more than 20 species; cf. Maletz et al., 1996), trilobites (about 30 species; cf. Tjernvik, 1956), and conodonts (about 23 species; cf. Löfgren, 1993; Maletz et al., 1996; Löfgren and Bergström, 2002). A small number of brachiopods and other shelly fossils have also been reported. Palynomorphs, especially acritarchs and chitinozoans, may occur but remain unstudied. However, the fact that these strata have been subjected to a heating of up to $600^{\circ} \mathrm{C}$, as indicated by CAI (Conodont Color Alteration Index; cf. Rejebian et al., 1987) values of 5-8 (Bergström, 1980; Löfgren, 1993; Löfgren and Bergström, 2002), is likely to have negatively affected the state of preservation of the palynomorphs. The vertical distribution of important taxa of graptolites, conodonts, and trilobites in the Diabasbrottet GSSP is illustrated in Figure 7, and each of these groups is discussed separately below.

\section{Graptolites}

As noted above, the common occurrence of taxonomically diverse and well-preserved graptolites in the Diabasbrottet area has been known for more than a century (Linnarsson, 1871; Holm, 1881)

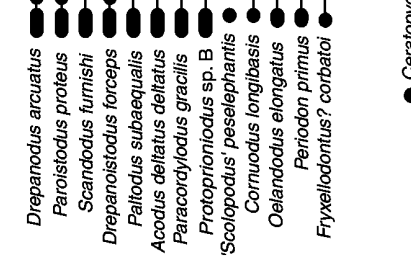

Figure 7 Vertical ranges of selected graptolites, conodonts, and trilobites in the Diabasbrottet section. Arrow marks the FAD of T. appoximatus and the base of the Second Stage. Slightly modified after Maletz et al. (1996). 


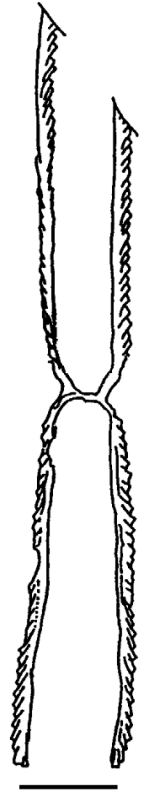

Figure 8 Outline drawing of a specimen of the index fossil Tetragraptus approximatus Nicholson from 3.4-3.5 $m$ above the top of the Cambrian at Diabasbrottet. Horizontal bar corresponds to $10 \mathrm{~mm}$. (From Maletz et al. 1996, Figure 13:1)

but the more recent studies by, in particular, Lindholm and Maletz have greatly improved our understanding of the graptolite biostratigraphy and the taxonomy of many taxa. A large number of species previously not known from the area have also been recorded. For a general summary of the vertical ranges of most biostratigraphically important graptolite taxa, see Maletz et al. (1996, Figures 4-8).

Because the definition of the base of the Second Stage of the Lower Ordovician in the Diabasbrottet GSSP is based on the first appearance (FAD) of the graptolite Tetragraptus approximatus (Figure 8), the graptolite biostratigraphy is an especially important component of the total biostratigraphy of the global stratotype. The lowest portion (about $2 \mathrm{~m}$ ) of the Tøyen Shale at sections along the southern and western flanks of Hunneberg contains a low-diversity assemblage, including Paradelograptus norvegicus, Hunnegraptus copiosus, Paradelograptus antiquus, and Tetragraptus bulmani, which is referred to the Hunnegraptus copiosus Zone (Lindholm 1991; Maletz et al., 1996; Maletz and Egenhoff, 2001). Single graptolite specimens occur throughout the zone but larger number of specimens are restricted to thin shale intervals. This graptolite fauna, which ranges up to the $\mathrm{E}$ bed, has not yet been found at Diabasbrottet where the corresponding stratigraphic interval is more calcareous than in the southern and western sections. However, the coeval part of the Diabasbrottet section can be recognized precisely based on conodont and trilobite biostratigraphy and its position relative to the E bed (Figure 9).

Typical specimens of T. approximatus appear just above the $\mathrm{E}$ bed at Diabasbrottet and in other sections, and none has been found below this limestone bed. Therefore, the top surface of the E bed, now marked by a 'golden spike', is taken to be the base of the Second Stage of the Lower Ordovician. However, this species is not the most common component in the diverse graptolite fauna of this interval, which also includes, among others, Azygograptus validus, Cymatograptus undulatus, Didymograptus demissus, D. rigoletto, Tetragraptus amii, and $T$. phyllograptoides. Based on the common occurrence of $T$. phyllograptoides, this interval has long been known as the T. phyllograptoides Zone in Scandinavian publications. At Hunneberg, this zone has been subdivided into a Lower and Upper Subzone (Lindholm, 1991) with a boundary (just above the $\mathrm{F} / \mathrm{G}$ bed) taken to be the level of appearance of Baltograptus geometricus and Didymograptus protobalticus. At about this level, several species disappear such as $A$. validus, C. undulatus, D. demissus, Holsbrotten
D. rigoletto, and T. phyllograptoides. At Diabasbrottet, the Lower Subzone contains more than a dozen graptolite species whereas nine species have been recorded from the Upper Subzone, including Paradelograptus smithii, P. mosseboensis, and T. vestrogothus. This subzone is overlain by the Didymograptus balticus Zone, which, apart from the zone index, is characterized by Baltograptus geometricus, B. vacillans, Corymbograptus vicinatus, Expansograptus ex gr. E. constrictus, and Pendeograptus fruticosus. Representative graptolite species from Hunneberg are illustrated by Maletz et al. (1996, Figure 13).

\section{Conodonts}

Although conodonts from the Tøyen Shale at Diabasbrottet were recorded and discussed by Lindström (1957) and Bergström (1988), our knowledge about the Lower Ordovician conodont biostratigraphy of the Hunneberg area is primarily based on Löfgren's (1993) detailed work that included study of a collection of more than 40000 specimens that were isolated from the limestone interbeds.

Löfgren (1993) showed that the base of the T.phyllograptoides Zone (=the FAD of T. approximatus) is within the Paroistodus proteus Zone. This zone was subdivided by Löfgren (1993) into four subzones. The boundary between the two upper of these subzones, the Paracodylodus gracilis Subzone and the Oelandodus elongatusAcodus deltatus deltatus Subzone, is near the base of the E bed, hence immediately below the global stage boundary (Figure 9). Furthermore, the base of the conodont zone above the $P$. proteus Zone, the widespread Prioniodus elegans Zone, appears to coincide with the F/G bed that marks the base of the Upper T. phyllograptoides Zone. For detailed conodont distribution data, see Maletz et al. (1996). It may be noted that not only is it possible to closely tie together the conodont and graptolite biostratigraphy at the Diabasbrottet and other Hunneberg sections but also, there is no discrepancy between these biostratigraphies.

\section{Trilobites}

In his classic study of Swedish regional Lower Ordovician trilobite faunas and biostratigraphy, Tjernvik (1956) investigated two sections on Hunneberg, namely the Storeklev and Mossebo sections. The latter locality is about $1 \mathrm{~km}$ south of, and in the same large quarry, as the Diabasbrottet section (Maletz et al., 1996, Figure 1)

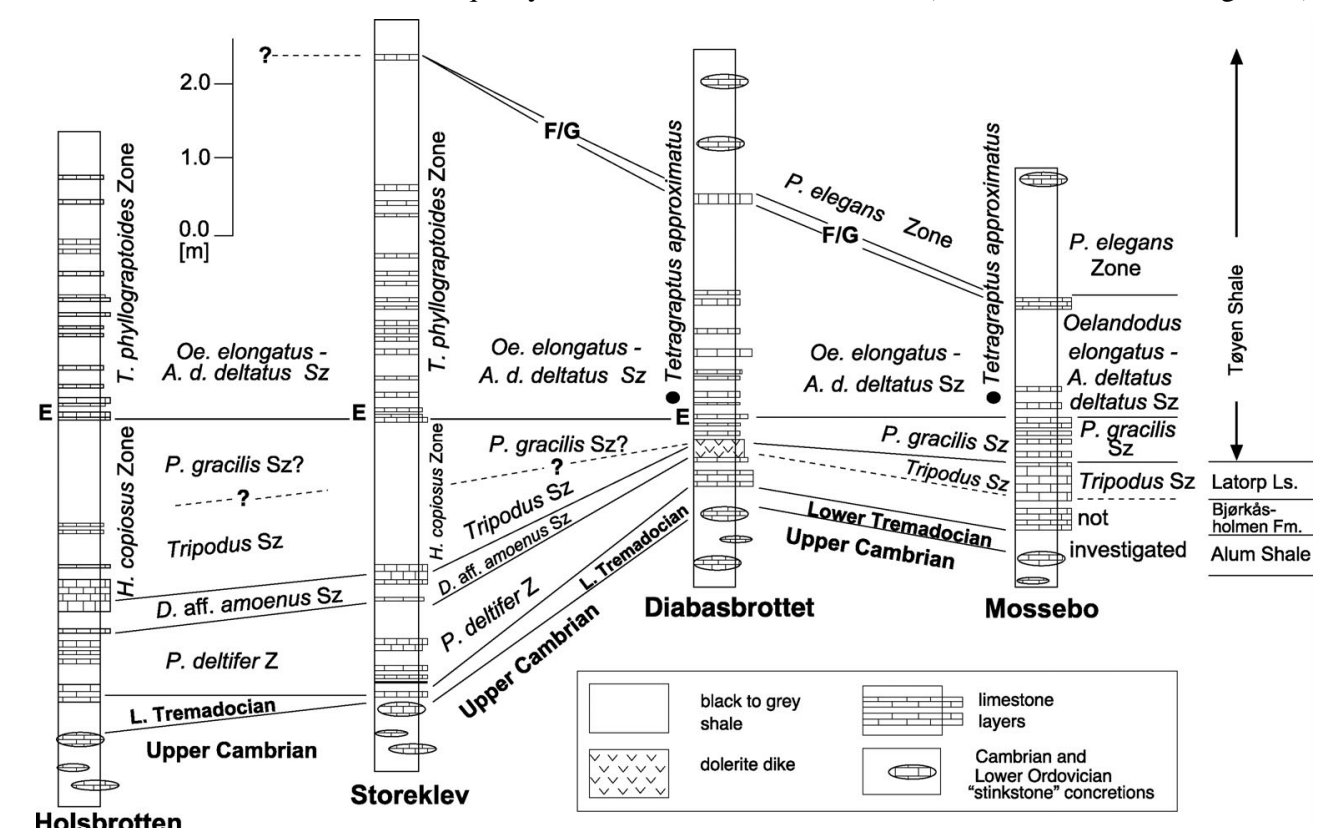

Figure 9 Biozone classification and correlation of the Diabasbrottet GSSP and some other Hunneberg sections. Note the position of the $\mathbf{H}$. copiosus Zone just below the $E$ bed at Holsbrotten and Storeklev. As shown by Löfgren and Bergström (2002), the conodont fauna of the $E$ bed at Holsbrotten is the same as that in the E bed at Diabasbrottet. 
and the lithologic and faunal successions are very similar in these two sections. Hence, Tjernvik's (1956) Mossebo data are also applicable to the GSSP section.

In the study interval, Tjernvik (1956) recognized three trilobite zones, the Apatokephalus serratus (now Ceratopyge forficula) Zone in the Bjørkåsholmen Formation, the Megistaspis (E.) armata Zone in the Latorp Limestone, and the $M$. (P.) planilimbata Zone in the Tøyen Shale. Representatives of the latter zone occur commonly in the limestone interbeds in the Tøyen Shale but are present also in the shale at some levels. Because the zone fossil of the $M$. (P.) planilimbata Zone appears at, or just below, the $\mathrm{E}$ bed, the base of this zone can be used for relatively precise recognition of the base of the Second Stage in shelly sections lacking graptolites. As shown by Tjernvik (1956), this trilobite zone ranges up to the F/G bed. The trilobite zone assignment of the uppermost part of the Tøyen Shale above this level was unclear to Tjernvik (1956) but later studies of other sections suggested to him (Tjernvik, 1980) that these strata were likely to be coeval with the M. (P.) aff. estonica Zone. As shown in Figure 7 , the base of this trilobite zone is very close to, if not the same as, the base of the Upper Tetragraptus phyllograptoides Zone and the base of the Prioniodus elegans Zone.

\section{Correlation of graptolite, conodont, and trilobite zones in the Hunneberg area}

The co-occurrence of taxonomically diverse and biostratigraphically diagnostic graptolite, conodont, and trilobite faunas is uncommon in Lower Ordovician strata anywhere in the world, and the Hunneberg sections offer a rare opportunity to directly tie these zonal schemes together. The relations between these zones in Hunneberg sections are illustrated in Figure 10.

\begin{tabular}{|c|c|c|c|c|c|c|}
\hline STAGES & FORMATIONS & \multicolumn{2}{|c|}{ GRAPTOLITE ZONES } & \multicolumn{2}{|c|}{$\begin{array}{l}\text { CONODONT ZONES } \\
\text { AND SUBZONES }\end{array}$} & TRILOBITE ZONES \\
\hline \multirow{2}{*}{ 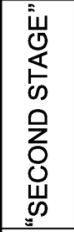 } & \multirow{2}{*}{ Tøyen } & $\begin{array}{l}\text { Upper } \\
\text { Tetragraptus } \\
\text { phyllo- }\end{array}$ & \multirow{2}{*}{ 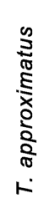 } & \multicolumn{2}{|r|}{$\begin{array}{l}\text { Prioniodus } \\
\text { elegans }\end{array}$} & $\begin{array}{l}\text { M. (P.) aff. } \\
\text { estonica }\end{array}$ \\
\hline & & $\begin{array}{c}\text { Lower } \\
\text { Tetragraptus } \\
\text { phyllo- } \\
\text { graptoides }\end{array}$ & & \multirow{4}{*}{ 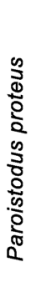 } & $\begin{array}{c}\text { Oelandodus } \\
\text { elongatus } \\
\text { Acodus d. } \\
\text { deltatus }\end{array}$ & $\begin{array}{l}\text { Megistaspis } \\
\text { (Para- } \\
\text { megistaspis) }\end{array}$ \\
\hline \multirow{4}{*}{ 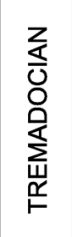 } & & \multirow{2}{*}{\multicolumn{2}{|c|}{$\begin{array}{l}\text { Hunnegraptus } \\
\text { copiosus }\end{array}$}} & & P. gracilis & \\
\hline & & & & & Tripodus & \\
\hline & & \multicolumn{2}{|c|}{$\begin{array}{c}\text { Araneograptus } \\
\text { murrayi } \\
\text { equivalent }\end{array}$} & & $\begin{array}{l}\text { Drep. aff. } \\
\text { D. amoenus }\end{array}$ & $\begin{array}{l}\text { Megistaspis } \\
\text { (Ekeraspis) } \\
\text { armata }\end{array}$ \\
\hline & $\begin{array}{l}\text { Bjørkåsholmen } \\
\text { Formation }\end{array}$ & \multicolumn{2}{|c|}{$\begin{array}{l}\text { Kiaerograptus } \\
\text { supremus } \\
\text { equivalent }\end{array}$} & \multicolumn{2}{|r|}{$\begin{array}{c}\text { Paltodus } \\
\text { deltifer }\end{array}$} & $\begin{array}{l}\text { Ceratopyge } \\
\text { forficula }\end{array}$ \\
\hline
\end{tabular}

Figure 10 Correlation of graptolite, conodont, and trilobite zones in the Hunneberg sections (slightly modified from Maletz et al., 1996).

\section{Chemostratigraphy and magnetostratigraphy}

The Diabasbrottet succession has been heated substantially by early Permian sills and dikes but it should have potential for chemostratiraphic studies using ${ }^{13} \mathrm{C}$, an isotope known to be preserved also in low-metamorphic rocks. Such a study is currently carried out by Schmitz and Bergström but results are not yet available. Interestingly, Buggisch et al. (2003) recently recognized a distinct negative ${ }^{13} \mathrm{C}$ excursion in the $P$. proteus Zone in the Argentine Precordillera but its precise relation to the stage boundary remains to be established. Accordingly, there is potential to broadly identify the stage boundary in terms of ${ }^{13} \mathrm{C}$ chemostratigraphy.

Due to the early Permian heating by sills and dikes, one must assume that the original paleomagnetic signature of the Hunneberg rocks has been reset and received a Permian overprint. Magnetic reversal stratigraphy has so far been little studied in the Ordovician and no reversal is known from the GSSP interval anywhere in the world.

\section{Comparison with the Cow Head succession}

As noted above, only one other section, "The Ledge" section on the Cow Head Peninsula of western Newfoundland, was formally proposed as a GSSP candidate for the Second Stage of the Lower Ordovician (Williams et al., 1994). Although a relatively detailed comparison between this section and that at Diabasbrottet was presented by Maletz et al. (1996), we feel it is appropriate to here summarize some pertinent facts about the proposed Newfoundland stratotype for a comparison with the Diabasbrottet GSSP. The general correlation between these successions is illustrated in Figure 11.

Unlike the Diabasbrottet succession, the Cow head sequence represents a slope deposit with numerous debris flows, several of which being quite large and some being located very close to the FAD of Tetragraptus approximatus. Some of these debris flows

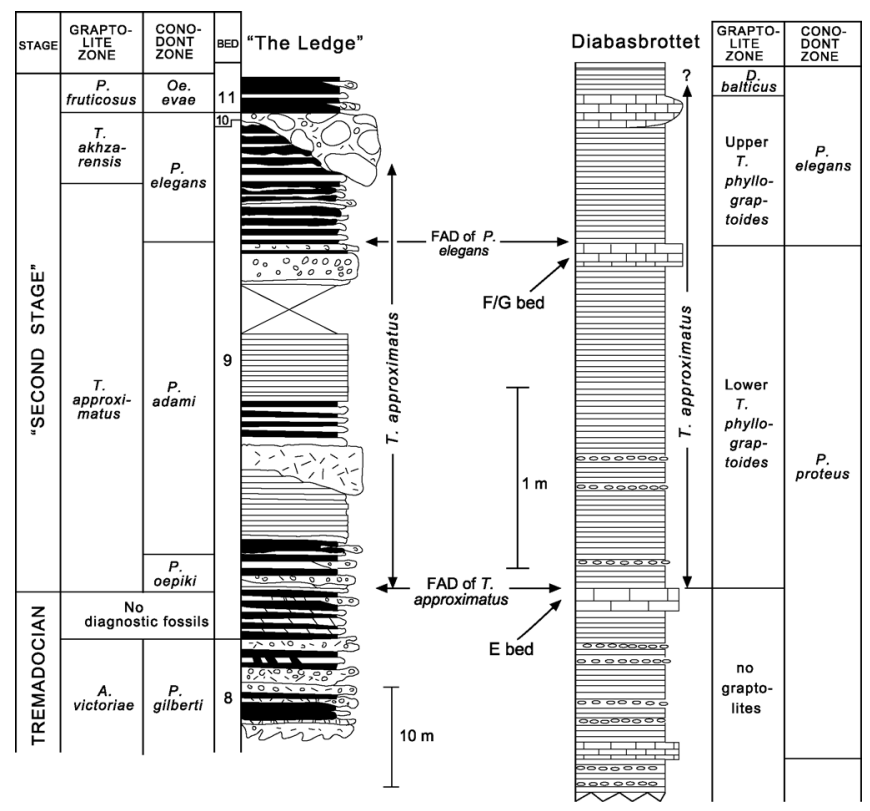

Figure 11 Lithologic and biostratigraphic comparison of "The Ledge" section, western Newfoundland and that at Diabasbrottet. The former section is redrawn after Stouge and Bognoli (1988, Figure 3). Note the similar range of $T$. approximatus in terms of conodont zones. The very different scale of the stratigraphic columns used for the comparison of stratigraphic relations suggests that the net rock accumulation rate in the slope succession of "The Ledge" was about 18 times higher than in the outer shelf sequence at Diabasbrottet.

show clear evidence of having removed parts of underlying strata during their down-slope movement, hence creating gaps in the stratigraphic succession. Carbonate interbeds have produced taxonomically diverse and biostratigraphically useful conodonts, and shaly beds contain graptolites of very low taxonomic diversity in the $T$. approximatus Zone. Reports that the lowest range of T. approximatus corresponds to the Prioniodus elegans Zone are now considered based on incorrect identifications. The interpretation by Stouge and Bagnoli (1988) that these beds rather correspond to the Baltoscandian Paroistodus proteus Zone is in good agreement with the known conodont/graptolite relations at Diabasbrottet and other Scandinavian localities (Maletz et al., 1996). The base of the Prioniodus elegans Zone is placed about $35 \mathrm{~m}$ above the FAD of T. approximatus by Stouge and Bagnoli (1988, Figure 3). The corresponding stratigraphic interval from the FAD of T. approximatus to the base of the $P$. elegans Zone is only about $2 \mathrm{~m}$ thick at Diabasbrottet (Figure 4) which illustrates the relatively rapid deposition of the Cow Head succession. 
A serious biostratigraphic problem with "The Ledge" section is that the bed with the FAD of T. approximatus is underlain by a $2 \mathrm{~m}+$ thick dolomitic interval that has failed to yield biostratigraphically diagnostic conodonts, graptolites, or other fossils. The lack of a continuous fossil record, especially immediately adjacent to the critical boundary horizon, obviously makes this section unsuitable as a GSSP. It could be argued that this almost barren interval represents a eustatic shallowing event that is also expressed by the much thinner $\mathrm{E}$ bed in the stratigraphically much more condensed successions at Diabasbrottet and other Hunneberg localities. The biostratigraphic data now available do not disprove this interpretation but more information is needed to confirm the correctness of this idea.

\section{Regional recognition of the base of the Second Stage}

Tetragraptus approximatus is a distinctive graptolite with a pandemic distribution. This wide distribution is particularly significant in view of the fact that Ordovician faunas show some of the most striking examples of paleobiogeographic differentiation known in the fossil record, and this applies not only to the benthic but also to the nectic and planktic faunas. As shown by Cooper and Lindholm (1990) and Maletz et al. (1996), T. approximatus has been recorded from Australia, New Zealand, Texas, Newfoundland, Canada, Taimyr, Kazakhstan, China, South America, Norway, and Sweden. Apparently because of absence of graptolitiferous rocks of the proper age, the species is not known from, for instance, Great Britain, Spitsbergen, and Africa. Although its ancestor remains unknown, based on the information now available, its FAD in most sections seems to be at about the same stratigraphic level (cf. Cooper and Lindholm, 1990), and its FAD appears to be useful for defining a global stage boundary in graptolite-bearing successions in many parts of the world..

However, in non-graptolite succession, one must rely on other fossils, and conodonts appear to have the best potential for locating the position of the stage boundary in such sequences. As noted above, the position of this stage level in the high to mid latitude Baltoscandian shelly successions can be recognized rather closely by means of conodonts and trilobites. In this stratigraphic interval, trilobites are as a rule provincial and of little use for correlations between continental plates. Also, the Lower Ordovician conodont faunas in the tropical zone differ greatly from those of Baltoscandia and very precise identification of the base of the Second Stage in equatorial shelly successions is currently not possible using these fossils. For instance, the diverse conodont faunas (Ethington and Clark, 1991) in the famous Lower Ordovician section in western Utah, which is the reference standard succession of the North American Lower Ordovician (Ibexian) Series (Ross et al., 1997), have so little in common with the Baltoscandic faunas that precise correlations are largely speculative. It is true that Ross et al. (1997) recognized an Acodus deltatus-Oneotodus costatus Zone in the middle to upper Ibexian Fillmore Formation, and provided the appearance of A. deltatus is coeval in Utah and S. Sweden, the base of the Second Stage would correspond to a level slightly more than $150 \mathrm{~m}$ above the base of this formation. Clearly, additional evidence is needed to confirm this very preliminary correlation.

\section{Proposed stage name}

At the present time, the precise stratigraphic level of the base of the Middle Ordovician Series as well as a GSSP section, which will serve as a global reference for the top of the Second Stage of the Lower Ordovician Series, have not been selected by the ISOS. Several potential stratotype sections have been proposed and are being considered by the ISOS, but no decision has yet been taken. Despite this, it may be appropriate to here propose a formal name for the Second Stage. In view of the statement in "The International Stratigraphic Guide" (in an abbreviated version by Murphy and Salvador, 1999) that 'the name of a stage should be derived from a geographic feature in the vicinity of its stratotype or type area,' it would seem desirable to select a name near the Diabasbrottet GSSP. The designation 'Hunnebergian' has been widely used as a Baltoscandic standard stage designation for an interval from well down in the upper Tremadocian to the base of the D. balticus Zone. Because it seems very likely that the base of the Middle Ordovician Series will ultimately be located considerably above the top of the D. balticus Zone, applying the term Hunnebergian to the Second Stage would require a drastic and surely undesirable redefinition of the wellknown stratigraphic scope of this provincial stage. Some recent authors have used the term "Latorpian Stage" for the postBjørkåsholmen, pre-Volkhovian interval but this is inappropriate in view of the original and now well-established use of this geographic name for a formation, the Latorp Limestone, the lower part of which is now classified as Tremadocian. The only significant settlement near Diabasbrottet is the Village of Flo, which is situated about $5 \mathrm{~km}$ S.E. of the stratotype (Figure 2). Although we realize that what is likely to be the stratigraphic scope of the Second Stage is not completely represented in the Hunneberg area, we are not aware of any provision that such a complete succession must be available near the geographic feature for which a chronostratigraphic unit is named. We therefore propose that the Second Stage be formally named the Floan Stage with its base defined by the GSSP at Diabasbrottet and its top by the GSSP for the Middle Ordovician Series, at a level and place to be decided. This designation has the advantage of being short, easily pronounced and spelled, and it has not been used previously as a stratigraphic term.

\section{Conclusions}

The Diabasbrottet sequence is a very condensed but stratigraphically remarkably complete, richly fossiliferous, outer shelf succession that fulfills most of the requirements of a GSSP. The GSSP is located in an old, long disused quarry just off a major highway and it will shortly be included in nature preserve that already exists adjacent to the GSSP site. There are no restrictions in terms of access or fossil collecting. The critical interval is exposed for several tens of $\mathrm{m}$ along a quarry wall and there are several similar sections nearby. One of these, the Mossebo section, has been studied in detail and it is proposed as an auxiliary stratotype section.

After a decade of work, the ISOS selected the Diabasbrottet as GSSP for the base of the Second (Upper) Stage of the Lower Ordovician and this decision was ratified by the ICS in 2002. The GSSP is about $2.1 \mathrm{~m}$ above the top of the Cambrian Alum Shale at the top surface of a laterally persistent limestone bed (the E bed) in the Tøyen Formation. This level is marked by the FAD of the Pacific Province graptolite zone index species Tetragraptus approximatus, which is the key fossil for defining the base of the stage. At Diabasbrottet, this species is a component of a high-diversity Atlantic Province fauna of the Tetragraptus phyllograptoides Zone, the base of which coincides with the stage boundary. In nearby sections, which can be correlated reliably with the Diabasbrottet succession, the lower Tøyen Shale just below the boundary E-bed contains graptolites of the Hunnegraptus copiosus Zone. The same stratigraphic interval has trilobites of the Megistaspis (E.) armata Zone, and conodonts of the Drepanodus aff. amoenus, Tripodus, and Paracordylodus gracilis Subzones of the Paroistodus proteus Zone. In terms of conodont biostratigraphy, the stage boundary is very near the base of the Oelandodus elongatus-Acodus deltatus deltatus Subzone of the Paroistodus proteus Zone. The base of the Megistaspis (P.) planilimbata Trilobite Zone is just below the stage boundary. Hence, the stage boundary is closely tied into the succession of three major index fossil groups. We propose that the Second stage of the Lower 
Ordovician be named the Floan Stage, this name being taken from the Village of Flo near the GSSP.

\section{Acknowledgements}

We are indebted to Stanley C. Finney and Chen Xu for reading the manuscript and offering useful comments.

\section{References}

Albanesi, G.L., 1988, Biofacies de conodontes de las sequencias Ordovicicas del Cerro Potrerillo, Precordillera Central de San Juan, R. Argentina:Actas de la Academia Nacional de Ciencias, Cordoba, vol. 12, pp. 75-98.

Bergström, S.M., 1980, Conodonts as paleotemperature tools in Ordovician rocks of the Caledonides and adjacent areas in Scandinavia and the British Isles: Geologiska Föreningens i Stockholm Förhandlingar, vol.102, pp. 337-392.

Bergström, S.M., 1988, On Pander's conodonts: Distribution and significance of the Prioniodus elegans fauna in Baltoscandia: Senckenbergiana lethaea, vol. 69, pp. 217-251.

Bergström, S.M., Finney, S.C., Chen X., Pålsson, C., Wang Z. and Grahn, Y., 2000, A proposed global boundary stratotype for the base of the Upper Series of the Ordovician System: The Fågelsång section, Scania, southern Sweden: Episodes, vol. 23, pp. 102-109.

Buggisch, W., Keller, M. and Lehnert, O., 2003, Carbon isotope record of Late Cambrian to early Ordovician carbonates of the Argentina Precordillera: Palaeogeography, Palaeoclimatology, Palaeogeography, vol. 195, pp. 357-373.

Chen X. and Bergström, S.M., (eds.) 1995, The base of the austrodentatus Zone as a level for global subdivision of the Ordovician System: Palaeoworld, vol. 5, pp. 1-127.

Cocks, L.R.M. and Rickards, R.B., (eds.) 1988, A global analysis of the Ordovician-Silurian boundary: Bulletin of the British Museum (Naural History) Geology, vol. 43, pp. 1-394.

Cooper, R.A. and Lindholm, K., 1990, A precise worldwide correlation of Early Ordovician graptolite sequences: Geological Magazine, vol. 127, pp. 497-525.

Cooper, R.A., Nowlan, G.S. and Williams, S.H., 2001, Global Stratotype Section and Point for base of the Ordovician System: Episodes, vol. 24, pp. 19-28.

Dronov, D. and Holmer, L.E., 1999, Depositional sequences in the Ordovician of Baltocandia, in Kraft, P. and Fatka, O., (eds), Quo vadis Ordovician? Acta Universitatis Carolinae geologica, vol. 43 (1/2), pp. 133-136.

Ethington, R.L. and Clark, D.L., 1981, Lower and Middle Ordovician conodonts from the Ibex area, western Millard County, Utah: Brigham Young University Geology Studies, vol. 28, pp. 1-160.

Erdtmann, B.-D., Maletz, J. and Gutierrez Marco, J.C., 1987, The new Early Ordovician (Hunneberg stage) graptolite genus Paradelograptus (Kinnegraptidae), its phylogeny and biostratigraphy: Paläontologische Zeitschrift, vol. 61, pp. 109-131.

Holm, G., 1881, Tvenne nya slägten af familjen Dichograptidae Lapw.: Öfversigt af Kongliga Vetenskaps-Akademiens Förhandlingar, vol. 9, pp. 45-51.

Jaanusson, V., 1960, On the series of the Ordovician System: 21st International Geological Congress, Proceedings, vol. 7, pp. 70-90.

Jaanusson, V., 1995, Confacies differentiation and upper Middle Ordovician correlation in the Baltoscandian Basin: Proceedings of the Estonian Academy of Sciences, Geology, vol. 44, pp. 73-86.

Lindholm, K., 1991, Ordovician graptolites from the early Hunneberg of southern Scandinavia: Palaeontology, vol. 34, pp. 283-327.

Lindström, M., 1957, Two Ordovician conodont faunas found with zonal graptolites: Geologiska Föreningens i Stockholm Förhandlingar, vol. 79, pp. 161-178.

Linnarsson, J.G.O., 1871, Om några försteningar från Sveriges och Norges Primordialzon: Öfversikt af Kongliga Vetenskaps-Akademiens Förhandlingar, vol. 6, pp. 789-797.

Löfgren, A., 1993, Conodonts from the Lower Ordovician at Hunneberg, south-central Sweden: Geological Magazine, vol. 120, pp. 215-232.

Löfgren, A. and Bergström, S.M., 2002, A stratigraphically significant conodont fauna from the base of the Tetragraptus approximatus Zone at Holsbrotten, Mt. Hunneberg, SW Sweden: GFF, vol. 124, pp. 131-134.

Maletz, J., 1987, Biostratigraphie und Graptolithenfauna im Unterordovizium des Hunneberges in Västergötland (westliches Zentralschweden):
Diplomarbeit Institut für Geologie und Paläontologie Georg August Universität, Göttingen, pp. 1-174.

Maletz, J. and Egenhoff, S.O., 2001, Late Tremadoc to early Arenig graptolite faunas of southern Bolivia and their implications for a worldwide biozonation: Lethaia, vol. 34, pp. 47-62.

Maletz, J., Löfgren, A. and Bergström, S.M., 1996, The base of the Tetragraptus approximatus Zone at Mt. Hunneberg, S.W. Sweden: A proposed Global Stratotype for the base of the Second Series of the Ordovician System: Newsletters in Stratigraphy, vol. 34(3), pp. 129-159.

Mitchell, C.E., Chen X., Bergström, S.M., Zhang Y., Wang Z., Webby, B.D and Finney, S.C., 1997, Definition of a global boundary stratotype for the Darriwilian Stage of the Ordovician System: Episodes, vol. 20, pp. 158166.

Murphy, M.A. and Salvador, A., (eds.) 1999, International Stratigraphic guide-An abridged version: Episodes, vol. 22, pp. 255-271.

Nielsen, A.H., 2003, Ordovician sea-level changes: potential for global event stratigraphy: INSUGEO, Serie Correlación Geológica, vol. 17, pp. 445449

Rejebian, V.A., Harris, A.G. and Huebner, J.S., 1987, Conodont color and textural alteration: An index to regional metamorphism, contact metamorphism and hydrothermal alteration: Geological Society of America Bulletin, vol. 99, pp. 471-479.

Ross, R.J., Jr., Hintze, L.F., Ethington, R.L., Miller, J.M., Taylor, M.E. and Repetski, J.E., 1997, The Ibexian, lowermost series in the North American Ordovician: U.S. Geological Survey Professional Paper 1579-A, pp.1-84.

Stouge, S. and Bagnoli, G., 1988, Early Ordovician conodonts from Cow Head Peninsula, western Newfoundland: Palaeontographia Italica, vol. 75 , pp. 89-179.

Tjernvik, T.E., 1956, On the early Ordovician of Sweden. Stratigraphy and fauna: Bulletin of the Geological Institutions of the University of Uppsala, vol. 36, pp. 107-284.

Tjernvik, T. E., 1980, The Latorp and Lanna-Volkhov Stages, in Tjernvik. T.E. and Johansson, J.V. (eds), Description of the upper portion of the drill-core from Finngrundet in the South Bothnian Bay: Bulletin of the Geological Institutions of the University of Uppsala, N.S., vol. 8, pp. 173193.

Törnquist, S.L., 1901, Researches into the graptolites of the lower zones of the Scanian and Vestrogothian Phyllo-Tetragraptus beds, Part 1: Lunds Universitets Årsskrift, vol. 37(2), pp. 1-26.

Törnquist, S.L., 1904, Researches into the graptolites of the lower zones of the Scanian and Vestergothian Phyllo-Tetragraptus beds, Part 2: Lunds Universitets Årsskrift, vol. 40(2), pp. 1-29.

Webby, W.B.N., 1996, ISOS Annual Report for 1995: Ordovician News, vol 13 , pp. 2-7.

Williams, S.H., Barnes, C.R., O’Brien, F.H.C. and Boyce, W.D., 1994, A proposed global stratotype for the Second Series of the Ordovician System: Cow Head Peninsula, western Newfoundland: Bulletin of Canadian Petroleum Geology, vol. 42, pp. 219-231.

Stig M. Bergström is Professor of Geological Sciences at the Ohio State University, USA where he has been teaching since 1968 after having received his graduate training at Lund University, Sweden. He has been a voting member of the International Subcommission on Ordovician Stratigraphy since 1974 and served as Subcomission Secretary in 1976-1982. His principal research interest is global Ordovician geology, especially aspects of the evolution of the Iapetus, the significance of Lower Paleozoic K-bentonites, and conodont and graptolite morphology and biostratigraphy.

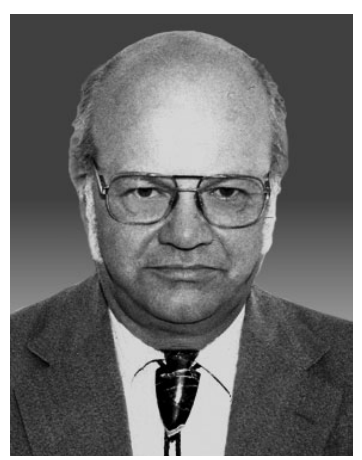

